\title{
Prevalence of Dental Caries among Primary School Children of Kathmandu District- A Pilot Study
}

\author{
Sunita Khanal, Rosina Bhattarai, G Nagaraja Rao, Sujita Shrestha \\ Department of Community dentistry, Kantipur Dental College, Kathmandu
}

\begin{tabular}{l}
\hline Correspondence \\
Dr. Sunita Khanal \\
Kantipur Dental College, \\
Basundhara, Kathmandu, Nepal \\
Email: \\
khanal.sunita729@gmail.com \\
ORCID ID: \\
http://orcid.org/0000-0002-1020-4854
\end{tabular}

DOI: http://dx.doi.org/10.3126/ jemsn.v13i2.16335

Article received: $30^{\text {th }}$ December 2016

Article accepted: $12^{\text {th }}$ June 2017

\begin{abstract}
Background \& Objectives: Worldwide, 60 to $90 \%$ of school children have experienced dental caries with higher prevalence in Asian and Latin American countries. A poor dental and oral health and untreated oral disease can have a significant impact on quality of life according to WHO report. The objectives of the study were to assess the prevalence of dental caries both in deciduous and permanent teeth and to compare total decayed, filled teeth surfaces among primary school children of Kathmandu from both government and private schools and to find the percentage of first permanent molars affected with dental caries. Materials \& Methods: A cross sectional study was conducted among two Government and two Private Primary School Children in Kathmandu district. Total sample were 468 children. Required permission were obtained from concerned authorities. WHO accepted indices for assessing caries designed by Henry $\mathrm{T}$ Klein, Carrole E Palmer and Knutson J.W was used. SPSS 20 version software was used for data analysis. Results: Among 468 primary school children examined, 224 were from Government and 244 were from Private school. The prevalence of dental caries was $62 \%$ and more deciduous teeth were decayed. The decayed, filled teeth surfaces in Private and Government school was statistically significant $(\mathrm{p}=0.000)$ but gender wise comparison of decayed, filled teeth surfaces was found to be statistically insignificant $(\mathrm{p}=0.303$ ). Among 1st Permanent Molar teeth examined, $85 \%$ were decayed. Conclusion: This pilot study showed prevalence of dental caries more in deciduous teeth. Among the permanent teeth affected, first permanent molars were in high number. Conclusion: This pilot study shows prevalence of dental caries more in deciduous teeth. Among the permanent teeth affected, first permanent molars are in high number.
\end{abstract}

Key words: Dental caries; Prevalence; School children

Citation: Khanal S, Bhattarai R, Rao NG, Shrestha S. Prevalence of Dental Caries among Primary School Children of Kathmandu District- A Pilot Study. JCMS Nepal. 2017;13(2):275-8.

\section{INTRODUCTION}

Dental caries is an irreversible microbial disease of the calcified tissues of teeth characterized by demineralization of the inorganic portion and destruction of organic substances of tooth which often leads to cavitations. ${ }^{1}$ Globally dental caries is a major public health problem due to its high prevalence and significant social impact. $^{2}$ The National Pathfinder survey of Nepal 2004 shows that $57.5 \%$ of five to six years age group and $25.6 \%$ of 12 to 16 years age group suffer from dental caries. Pain and discomfort due to untreated dental caries was $18 \%$ in five to six year olds. ${ }^{3}$ Dental caries is most prevalent and chronic oral disease of childhood having multifactorial etiology. The etiological factors are host factors, microorganisms, diet and time. $^{4}$

The dental caries burden has been increasing among children due to the unlimited consumption of sugary substances, poor oral care practices and inadequate 
health service utilization. ${ }^{4}$ Many children fail to brush their teeth effectively and tend to consume cariogenic foods and may underestimate health risks despite having basic knowledge of dental health, such as importance of proper brushing and diet in preventing dental caries. ${ }^{5}$ Poor oral health can have negative impacts on children's quality of life and academic performance apart from causing chronic pain and discomfort .If untreated it can impact daily activities in terms of play, sleep, eating and school activity. ${ }^{6}$ As dental caries is the most common dental disease with high prevalence it is necessary to control the disease by assessing and rendering the treatment required along with spreading awareness regarding its prevention. ${ }^{7}$

\section{Objectives}

- To assess the prevalence of dental caries both in deciduous and permanent teeth and to compare the decayed, filled teeth surfaces (dfs) in both government and private schools.

- To compare the decayed, missing and filled teeth surfaces (dfs) gender wise

- To find the percentage of first permanent molars affected with dental caries

\section{MATERIALS AND METHODS}

A cross sectional study was conducted among two government and two private primary school children in Kathmandu district during the three months' period i.e. from February-April 2016. Ethical clearance was obtained from Institutional Review Committee of Kantipur Dental College. Required permission were obtained from concerned authorities i.e. Principal of each school. Prior consent was also taken from the parents of each children. Along with the consent form the questionnaire was also sent to the parents from which the details were obtained. Convenience sampling method was used for ease in data collection purpose. The sample size was calculated using average of the prevalence of dental caries in five to six years and 12 to 16 years age group. ${ }^{3}$ The formula $n=Z^{2} p q / E^{2}$ was used and the sample size calculated was 372. Clinical examination was conducted among 468 school children. Oral examination was carried out by a single trained examiner and for data entry trained assistant was used. WHO accepted indices for assessing caries designed by Henry T Klein, Carrole E Palmer and Knutson J.W has been used. ADA type 3 examination was done. Instruments used were mouth mirror and explorer.
Inclusion criteria: Students of both gender who were present on the day of examination was taken

Exclusion criteria: Students those were absent on the day of examination was excluded. Missing component has been excluded because children were not able to answer whether the tooth was extracted due to caries or pre shedding mobility.

Statistical analysis: SPSS 20 version software was used for data analysis. Mann Whitney test was used to see the statistical significance and $p \leq 0.05$ was considered statistically significant.

\section{RESULTS}

The study population were 468 primary school children of five to 15 years age group. Total number of students in government schools were 224 and total students in private schools were 244 (Table no.1). Total students using fluoridated toothpaste were $74.1 \%$ and non-fluoridated toothpaste were $25.6 \%$.. The prevalence of dental caries in five to 10 years' age group was $60.70 \%$ and in 11 to 15 age group was $39.30 \%$. The prevalence of dental caries in deciduous teeth was $62 \%$ and in permanent teeth was $22.90 \%$. Total decayed surfaces, filled surfaces, total dfs and first permanent decayed molars in government and private school children of age group five to 10 years is shown in (Table no.2) Total decayed surfaces, filled surfaces, total $\mathrm{dfs}$ and first permanent decayed molars in government and private school children of age group 11 to 15 years is shown in (Table no.3) The comparison of decayed, filled teeth surfaces in private and government schools was found to be statistically significant. Gender wise comparison of the decayed, filled teeth surfaces was found to be statistically insignificant (Table no.4 and 5)

\section{Table no.1 Distribution of government and} private school children by age and sex

\begin{tabular}{lllll}
$\begin{array}{l}\text { Age } \\
\text { (Years })\end{array}$ & School & \multicolumn{2}{l}{ Gender } & Total \\
& & Male & Female & \\
$5-10$ & Govt & 48 & 67 & 115 \\
& Private & 98 & 70 & 168 \\
$11-15$ & Govt & 46 & 63 & 109 \\
& Private & 40 & 36 & 76
\end{tabular}


Table no. 2 Decayed, filled, total dfs and first permanent decayed molars in government and private schools (5-10 years)

\begin{tabular}{|c|c|c|c|c|c|c|c|c|c|c|c|}
\hline \multirow{2}{*}{$\begin{array}{l}\text { Type of } \\
\text { dentitio } \\
n\end{array}$} & \multirow{2}{*}{ School } & \multirow{2}{*}{$\begin{array}{l}\text { teeth } \\
\text { Male }\end{array}$} & \multirow{2}{*}{$\begin{array}{l}\text { Decayed } \\
\text { Femal } \\
\text { e }\end{array}$} & \multicolumn{2}{|c|}{ Filled teeth } & \multicolumn{2}{|c|}{$\begin{array}{l}\text { No of decayed } \\
\text { surfaces }\end{array}$} & \multicolumn{2}{|c|}{ Total (dfs) } & \multicolumn{2}{|c|}{$\begin{array}{l}\text { No on decayed } \\
\text { permanent firs } \\
\text { molar }\end{array}$} \\
\hline & & & & Male & $\begin{array}{l}\text { Fema } \\
\text { le }\end{array}$ & Male & Female & Male & Female & Male & $\begin{array}{l}\text { Femal } \\
\text { e }\end{array}$ \\
\hline \multirow{2}{*}{$\begin{array}{l}\text { Permane } \\
\text { nt }\end{array}$} & Govt & 19 & 15 & - & - & 25 & 16 & 25 & 16 & $\begin{array}{l}13 \\
(68.4 \\
\%)\end{array}$ & $\begin{array}{l}15 \\
(100 \\
\%)\end{array}$ \\
\hline & Private & 40 & 26 & 1 & 2 & 48 & 28 & 49 & 30 & $\begin{array}{l}40 \\
(100 \\
\%)\end{array}$ & $\begin{array}{l}22 \\
(84.6 \\
\%)\end{array}$ \\
\hline \multirow{2}{*}{$\begin{array}{l}\text { Deciduo } \\
\text { us }\end{array}$} & Govt & 108 & 164 & 1 & - & 191 & 291 & 192 & 291 & - & - \\
\hline & Private & 313 & 212 & 16 & 9 & 548 & 334 & 564 & 343 & - & - \\
\hline
\end{tabular}

Table no.3 Decayed, filled, total dfs and first permanent decayed molars in government and private schools (11-15 years)

\begin{tabular}{|c|c|c|c|c|c|c|c|c|c|c|c|}
\hline \multirow[t]{2}{*}{$\begin{array}{l}\text { Type of } \\
\text { dentition }\end{array}$} & \multirow[t]{2}{*}{ School } & \multicolumn{2}{|c|}{ Decayed teeth } & \multicolumn{2}{|c|}{ Filled teeth } & \multicolumn{2}{|c|}{$\begin{array}{l}\text { No of decayed } \\
\text { surfaces }\end{array}$} & \multicolumn{2}{|c|}{$\begin{array}{l}\text { Total (dfs) } \\
\text { DFS }\end{array}$} & \multicolumn{2}{|c|}{$\begin{array}{l}\text { No on decayed } \\
\text { permanent first } \\
\text { molar }\end{array}$} \\
\hline & & Male & $\begin{array}{l}\text { Fema } \\
\text { le }\end{array}$ & Male & $\begin{array}{l}\text { Fema } \\
\text { le }\end{array}$ & Male & $\begin{array}{l}\text { Fema } \\
\text { le }\end{array}$ & Male & $\begin{array}{l}\text { Fem } \\
\text { ale }\end{array}$ & Male & $\begin{array}{l}\text { Fema } \\
\text { le }\end{array}$ \\
\hline \multirow[t]{2}{*}{ Permanent } & Govt & 29 & 30 & - & - & 29 & 30 & 30 & 45 & $\begin{array}{l}26 \\
(89.6 \%\end{array}$ & $\begin{array}{l}26 \\
(86.6 \\
\%)\end{array}$ \\
\hline & Private & 30 & 9 & 1 & - & 31 & 21 & 32 & 21 & $\begin{array}{l}26 \\
(86.6 \%\end{array}$ & $\begin{array}{l}8 \\
(88.6 \\
\%)\end{array}$ \\
\hline \multirow[t]{2}{*}{ Deciduous } & Govt & 36 & 35 & 7 & - & 52 & 57 & 59 & 57 & - & - \\
\hline & Private & 30 & 57 & 4 & 4 & 58 & 109 & 62 & 113 & - & - \\
\hline
\end{tabular}

\section{DISCUSSION}

This study was conducted to assess the prevalence of dental caries in both deciduous and permanent dentition of age groups five to 10 years and 11 to 15 years primary school children of both government and private school in Kathmandu district and to know total decayed, filled teeth surfaces(dfs).The overall prevalence of dental caries in primary teeth was found to be $62 \%$ which is similar to other study ${ }^{8}$ but in contrast to other studies. ${ }^{9,10}$ The prevalence of dental caries in five to 10 years was greater than in 11 to 15 years and was similar to the prevalence rate given by National Pathfinder survey of Nepal $(2004)^{3}$ similar findings were there in other studies ${ }^{4,5,2}$ This may be due to the fact that caries is a cumulative process and children were observed to have preference to caries prone foods available near the school premises. ${ }^{9}$ Also it could be due to lack of parental awareness/prioritization for care, affordability issues, issues of child neglect etc. ${ }^{11}$ But this finding was in contrast to the study done by Khanal S and Acharya J. ${ }^{5}$ The prevalence of dental caries was found to be higher in deciduous and lower in permanent dentition which is similar to other studies. ${ }^{9,12}$ This could be due to increased awareness of oral hygiene with increasing age and greater resistant property of permanent teeth to caries process than the primary teeth. ${ }^{13}$ But this finding is in contrast to another study. ${ }^{10}$ There was significant difference in the prevalence of dental caries in private school children and government school children which is similar to other studies. ${ }^{7,14}$ Among the studied population, 5 to 10 years had maximum number of decayed teeth compared to 11 to 15 years' age groups with negligible filled component. Among the decayed permanent molars, first permanent molars were very high in number i.e. more than $85 \%$ which is similar to the study 
Table number 4. Comparison of dfs between private and government school (Mann Whitney Test)

$\begin{array}{llll}\text { Institution } & \begin{array}{l}\text { Mean } \\ \text { dfs }\end{array} & \text { SD } & p \text { value } \\ \text { Private } & 2.66 & 2.571 & 0.000^{*} \\ \text { Government } & 1.55 & 2.024 & \end{array}$

$*=$ statistically significant

\section{Table number 5. Comparison of dfs between male and female (Mann Whitney test)}

\begin{tabular}{llll} 
Sex & $\begin{array}{l}\text { Mean } \\
\text { dfs }\end{array}$ & SD & $p$ value \\
Male (233) & 2.24 & 2.307 & 0.133 \\
$\begin{array}{l}\text { Female } \\
\text { (235) }\end{array}$ & 2.02 & 2.465 & \\
\hline
\end{tabular}

done by Khalid H.M.Al-Samadani and Mohammad Sami Ahmad. ${ }^{15}$ No significant differences were found between prevalence of dental caries in girls and boys which is similar to other studies ${ }^{15,16}$ but is different from other studies. ${ }^{5,7,17}$

\section{CONCLUSION}

From the above results we have seen that the decayed portion constituted the major portion of dfs, with almost negligible filled component. Therefore, in a country like Nepal, focus should be given on prevention rather than on treatment. The prevalence of dental caries was higher in deciduous teeth compared to permanent teeth. Among the permanent teeth decayed, first permanent molars were high in number i.e. more than $85 \%$ which is of concern. Screening, preventive programs, health education and parent motivation can help in reducing the incidence of dental caries in children.

\section{Limitations}

As this is a pilot study, the sample size is limited and findings cannot be generalized. Further survey work can be done on more number of children to confirm our findings.
Health. 2013;13(1):1.

3. Yee R, Mishra P. Nepal national oral health pathfinder survey 2004. Kathmandu, Nepal Oral Health Focal Point. 2004;

4. Mulu W, Demilie T, Yimer M, Meshesha K, Abera B. Dental caries and associated factors among primary school children in Bahir Dar city: a cross-sectional study. BMC Res Notes. 2014;7(1):1-7. https://doi.org/10.1186/17560500-7-949. PMID: 25540044.

5. Khanal S, Acharya J. Dental caries status and oral health practice among 12-15 year old children in Jorpati, Kathmandu. Nepal Med Coll J. 2014;16(1):84-7.

6. Mafuvadze BT, Mahachi L, Mafuvadze B. Dental caries and oral health practice among 12 -year-old school children from low socio-economic status background in Zimbabwe. Pan Afr Med J. 2013; 14:164-9. https://doi.org/10.11604/ pamj.2013.14.164.2399. PMID: 23819006.

7. Fotedar Shailee, M. Sogi Girish, R. Sharma Kapil PN. Oral health status and treatment needs among 12 and 15-year-old government and private school children in Shimla city, Himalchal Pradesh, India. J Int Soc Prev community Dent. 2013;3(1):44-50. 0762.115715. PMID: 24478980.

8. Rugg-gunn AJ. National Oral Health Survey, Sri Lanka, 1994/95. Int J Paediatr Dent. 2003;13(1):72-3.

9. Hiremath A, Murugaboopathy V, Ankola A V, Hebbal M. Prevalence of Dental Caries Among Primary School Children of India - A Cross-Sectional Study. J Clin Diagnostic Res. 2016;10(10):47-50. https:// doi.org/10.7860/jcdr/2016/22474.8642.

10. Farooqi FA, Khabeer A, Moheet IA, Khan SQ, Farooq I, Arrejaie AS. Prevalence of dental caries in primary and permanent teeth and its relation with tooth brushing habits among schoolchildren in Eastern Saudi Arabia. Saudi Med J. 2015;36(6):737-42. https://doi.org/10.15537/ smj.2015.6.10888. PMID:25987118.

11. Rajesh SS, Venkatesh P. Prevalence of dental caries among school-going children in South India. Int J Med Sci Public Health. 2016;5(4):700-4. https://doi.org/10.5455/ ijmsph.2016.27082015115.

12. TK Bhagat AS. Original research article prevalence of Dental caries among public school children. J Chitwan Med Coll. 2014;4(7):30-2.

13. Sudha P, S Bhasin RA. Prevalence of dental caries among 5-13-year-old children of Mangalore city. J Indian Soc Pedod Prev Dent. 2005;23(2):74-9. https:// doi.org/10.4103/0970-4388.16446. PMID: 16012209.

14. Halwai HK, Bhat PK, Shekhar M, Yadav B. Oral Health Status and Treatment Needs among 12 and 15-year-old Government and Private School Children in Rupandehi District (Bhairahawa) Nepal. J Universal Coll Med Sci. 2014;2(3):15-9. https://doi.org/10.3126/jucms.v2i3.11822.

15. Al-Samadani KHM, Ahmad MS. Prevalence of First Permanent Molar Caries in and Its Relationship to the Dental Knowledge of 9-12-Year Olds from Jeddah, Kingdom of Saudi Arabia. Int Sch Res Netw. 2012; 2012:1 -6. https://doi.org/10.5402/2012/391068.

16. Rathod SB, Nimbal A V. Prevalence of Dental Caries among the Government Primary School Children at Ukkali District Vijayapura: A Correlated Prevalence Survey. J Chem Pharm Res. 2016;8(7):22-5.

17. Prabhu S, John J. Dental caries prevalence among 12-yearold school children from urban and rural areas in Tamil Nadu. e-Journal Dent. 2013;13(1):326-30.

\section{REFERENCES}

1. Rajendran R. Shafer'S Textbook of Oral Pathology (6Th Edition). Elsevier (A Divisionof Reed Elsevier India Pvt. Limited); 2009.

2. Dixit LP, Shakya A, Shrestha M, Shrestha A. Dental caries prevalence, oral health knowledge and practice among indigenous Chepang school children of Nepal. BMC Oral 